УДК 94(477):323.1]:323.282"1944/1950"

DOI https://doi.org/10.24919/2308-4863/42-1-3

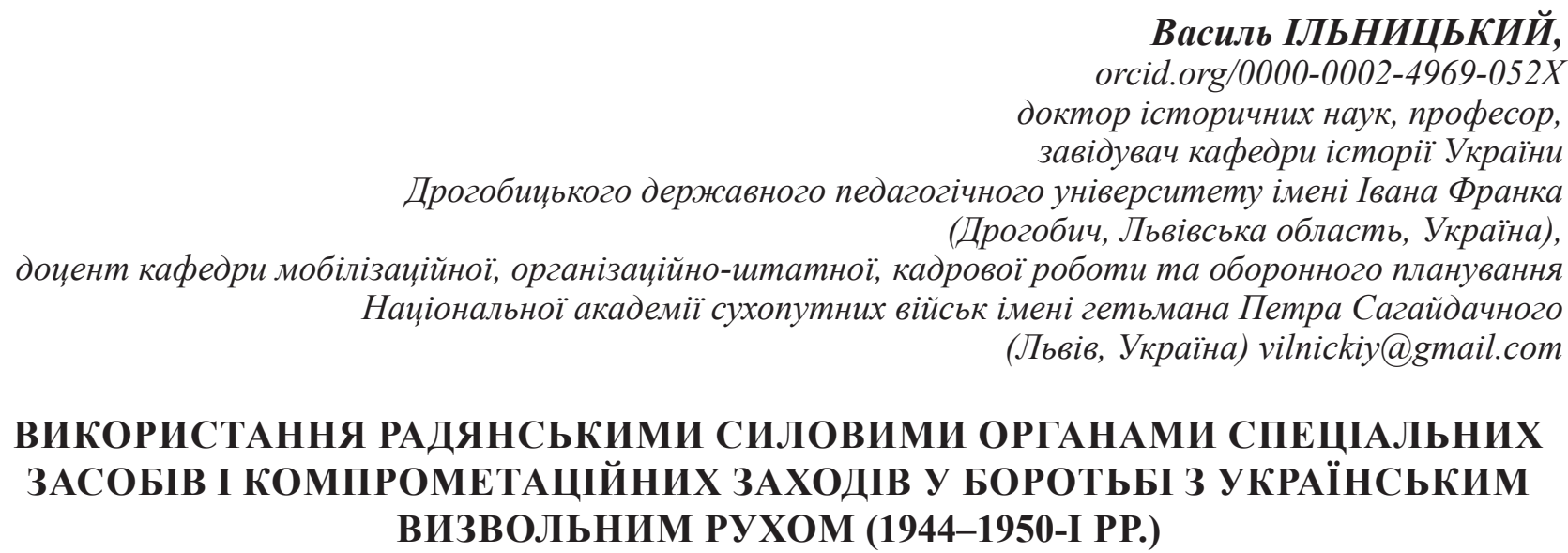

У статті на основі невідомих і маловідомих джерел розкриваються особливості застосування репресивнокаральними органами різноманітних спеціальних засобів - технологічних, хімічних, бактеріологічних - $i$ використання службово-розшукових собак $і$ компрометації підпільників. Доведено, щзо в боротьбі з визвольним рухом репресивно-каральні органи не лише покладалися на військову силу, а й використовували різноманітні, в окремих випадках навіть «витончені» форми (радіосигналізаційні апарати «Тривога», «Метео», службово-пошукові собаки, «приманки» (иінні речі, продовольчі товари, агенти, рідче радянські чиновники), снодійні й отруйні препарати, поширення різноманітних недуг, компрометаціi). Зокрема, масово застосовувалися спеціальні засоби, які поступово вдосконалювалися. Водночас у дослідженні наведені приклади успішних і неуспішних випадків застосування спеизасобів і компрометаційних заходів, виокремлені їх причини. На початкових етапах боротьби основним завданням, яке ставив репресивно-каральний апарат, було фізичне знищення членів ОУН та УПА. Згодом увага акцентувалася на захопленні підпільників живими з метою подальшого використання для ліквідації визвольного руху в Україні й оперативних «ігор» із націоналістичними закордонними иеетрами. При иъьому основний наголос робився на захопленні чи знищення передусім керівного складу. Водночас, не маючи можливості фізично знищити націоналіста (особливо керівника), спецслужби до свого арсеналу широко вводили компрометаиіiі. Для иьього ретельно вивчали особистість підпільника, якого намагалися дискредитувати, його зв'язки, проступки, слабкості тощьо. Попри значну частину ефективних компрометаційних заходів, траплялися провали, щуо, очевидно, зумовлювалося вмінням ретельно розібратися в обставинах Службою безпеки ОУН.

Ключові слова: спеціальні засоби, компрометація, репресивно-каральні органи, украйнський визвольний рух.

Vasyl ILNYTSKYI, orcid.org/0000-0002-4969-052X

PhD hab. (History), Associate Professor, Head of the Department of Ukraine's History Ivan Franko Drohobych State Pedagogical University (Drohobych, Lviv regoin, Ukraine), Associate Professor at the Department of Mobilization, Organizational, Staffing, Human Resources and Defense Planning National Academy of Land Forces named after Petro Sahaidachnyi (Lviv,Ukraine)vilnickiy@gmail.com

\title{
USE OF SPECIAL MEANS AND COMPROMISATIVE MEASURES BY SOVIET FORCES IN THE FIGHT AGAINST THE UKRAINIAN LIBERATION MOVEMENT IN 1950 AND 1950
}

The article, based on unknown and little-known sources, reveals the peculiarities of the use of repressive and punitive bodies of various special means - technological, chemical, bacteriological and the use of search dogs and compromising underground. It is proved that in the struggle against the liberation movement repressive and punitive bodies relied not only on military force, but also used various, in some cases even "sophisticated" forms (radio alarms "Alarm", "Meteo", search dogs, baits (Valuables, food, agents, rarely Soviet officials), sleeping pills and poisons, the spread of various diseases, compromises). In particular, special means were widely used, which were gradually improved. At the same time, the examples of successful and unsuccessful cases of application of special means and compromising measures are given 
in the researched, their reasons are singled out. In the initial stages of the struggle, the main task set by the repressive and punitive apparatus was the physical destruction of members of the OUN and UPA. Subsequently, attention was focused on capturing the underground alive for further use to eliminate the liberation movement in Ukraine and for operational "games" with nationalist foreign centers. The main emphasis was on the capture or destruction of the leadership for the first time. At the same time, not being able to physically destroy the nationalist (especially the leader), the secret services widely introduced compromises into their arsenal. To do this, they carefully studied the identity of the underground member they were trying to discredit, his connections, misdeeds, weaknesses, and so on. Despite a significant number of effective compromising measures, there were failures, which was obviously due to the ability of the OUN Security Service to thoroughly understand the circumstances.

Key words: special means, compromise, repressive and punitive bodies, Ukrainian liberation movement.

Постановка проблеми. Сучасна українська історична наука в останні роки збагатилася значною кількістю різноаспектних та об’єктивних досліджень українського визвольного руху 1940-1950-х рр. Попри це, у цій проблематиці залишається значна кількість недосліджених аспектів, та й вона надалі не знаходить однозначної оцінки в суспільстві. Навіть більше - продовжують 3'являтися праці, у яких діяльність ОУН і УПА висвітлюється 3 позицій колишньої офіційної радянської історичної науки. Така ситуація зумовлює ще більшу актуальність грунтовного (на основі залучення широкого джерельного матеріалу) вивчення специфіки функціонування українського визвольного руху народу 1940-1950-х рр. Водночас одним із завдань визначається необхідність розкриття масштабів, форм і методів (у тому числі спеціальних) боротьби репресивно-каральної системи проти ОУН та УПА.

Аналіз досліджень. Звісно, до питання використання радянськими силовиками спеціальних засобів і компрометаційних заходів зверталася ціла низка вчених, зокрема ця проблема висвітлена в узагальнених дослідженнях І. Біласа (Білас, 1994a; Білас, 1994b), Ю. Киричука (Киричук, 2000; Киричук, 2003), А. Кентія (Кентій, 1999а; Кентій, 1999b), А. Русначенка (Русначенко, 2002), Д. Вєдєнєєва та Г. Биструхіна (Вєдєнєєв, Биструхін). Різноманітні форми й методи боротьби репресивно-каральних органів із ОУН та УПА розкриті у збірниках документів, підготовлених В. Сергійчуком (Сергійчук, 1998; Сергійчук, 2005).

Оригінальне дослідження, присвячене використанню допоміжних засобів у боротьбі з підпіллям, - робота О. Іщука та Н. Ніколаєвої. Питання використання радянськими каральнорепресивними органами спецзасобів у боротьбі проти визвольного руху в Карпатському краї ОУН (1945-1954) досліджував В.Ільницький (Ільницький, 2014). Особливості формування радянських силових органів вивчав В. Ільницький (Ільницький, 2015). Створення винищувальних батальйонів і залучення їх до боротьби з українськими націоналістами в Дрогобицькій області розкрили В. Ільницький та М. Галів (Ільницький, Галів, 2009).

Мета статті - використовуючи невідомі та маловідомі архівні джерела, розкрити особливості використання радянськими репресивнокаральними органами спецзасобів і компрометаційних заходів у боротьбі проти українського визвольного руху.

Виклад основного матеріалу. Репресивнокаральні органи вдалися до застосування найрізноманітніших спеціальних засобів - технологічних, хімічних, бактеріологічних, практикувалися заходи 3 компрометації підпільників, використання службово-розшукових собак тощо.

Одним зі спецзасобів у боротьбі проти визвольного руху були радіосигналізаційні апарати «Тривога». Їх застосування в агентурно-оперативній роботі органами МДБ західних областей України забезпечувало швидкий і конспіративний зв'язок 3 агентурою, подання по радіо сигналу про появу підпільників, що суттєво допомагало чекістам у справі їхнього оперативного розшуку. Функціональні особливості цього апарату давали змогу конспіративно й без зволікань установлювати апарат. Для цього підбирали довірених агентів, у помешканні яких маскували пристрій «Тривога» (технічні можливості давали змогу навіть закопувати його в землю). При появі націоналістів агентові достатньо було натиснути на кнопку, і сигнал надходив до районного відділу МДБ, туди відразу відправлялася оперативно-військова група. Такий пристрій сприяв швидкому інформуванню, а чекісти могли реагувати на появу підпільників, а також тримати в таємниці агента, який надсилав повідомлення.

Радіосигналізаційну техніку почали широко використовувати в західних та окремих східних областях України з червня 1948 р. На Станіславщині в 1948 р. нараховувалося 100 комплектів сигналізаційних апаратів «Тривога», які використовувалися при чекістських заходах (ГДА СБУ. Ф. 13. Спр. 372. Т. 56. Арк. 157; Т. 90. Арк. 66; Іщук, Ніколаєва, 2008: 154-155). Цим пояснюється широке використання радіосигналізаційної 
апаратури. Лише на території Солотвинського р-ну в 1948 р. було розміщено 28 радіосигналізаційних апаратів «Тривога» (приблизно два на село) (Проданик, 2011: 33). За 9 місяців 1950 р. у західних областях України за допомогою радіосигналізаційної техніки було ліквідовано значну кількість підпільників (ГДА СБУ. Ф. 13. Спр. 372. Т. 90. Арк. 1). Усього упродовж червня 1948-грудня 1950 рр. у західних областях України проведено 1169 установок радіосигналізаційних апаратів «Тривога», 3 яких було прийнято 186 радіосигналів про появу підпільників, реалізовано 52, що сприяло захопленню й ліквідації 136 підпільників (на 1 січня 1951 р. діяли 87 апаратів); із них по УМДБ Станіславської області здійснено 182 установки радіосигналізаційних апаратів «Тривога», з яких було прийнято 23 радіосигнали про появу підпільників, реалізовано 10, що дало змогу захопити й ліквідувати 69 націоналістів (на 1 січня 1951 р. діяли шість апаратів); відповідно, УМДБ Львівській області здійснено 282 установки радіосигналізаційних апаратів «Тривога», 3 яких було прийнято 51 радіосигнал про появу підпільників, реалізовано 11, що дало змогу захопити й ліквідувати 28 націоналістів (на 1 січня 1951 p. діяли 42 апарати); УМДБ Дрогобицькій області проведено 131 установку радіосигналізаційних апаратів «Тривога», 3 яких було прийнято 25 радіосигналів про появу підпільників, реалізовано п'ять, що уможливило захопити й ліквідувати шістьох осіб (на 1 січня 1951 р. діяли 11 апаратів); у Тернопільській області здійснено 171 установку радіосигналізаційних апаратів «Тривога», з яких було прийнято 24 радіосигнали про появу підпільників, реалізовано 3, що дало змогу захопити й ліквідувати 10 націоналістів (на 1 січня 1951 p. діяли 7 апаратів); у Рівненській області здійснено 190 установок радіосигналізаційних апаратів «Тривога», з яких було прийнято 30 радіосигналів про появу підпільників, реалізовано 5 , що дало змогу захопити й ліквідувати 9 націоналістів (на 1 січня 1951 р. діяли 13 апаратів); у Волинській області здійснено 94 установки радіосигналізаційних апаратів «Тривога», з яких було прийнято 17 радіосигналів про появу підпільників, реалізовано 9, що дало змогу захопити й ліквідувати 10 націоналістів (на 1 січня 1951 р. діяли 2 апарати); у Чернівецькій області проведено 15 установок радіосигналізаційних апаратів «Тривога», 3 яких було прийнято два радіосигнали про появу підпільників, реалізовано один, у результаті чого вдалося захопити й ліквідувати двох підпільників (на 1 січня 1951 р. діяв один апарат); у Закарпатській області проведено дев'ять установок радіосигналізаційних апаратів «Тривога», з яких було прийнято один радіосигнал про появу підпільників, реалізовано один, що допомогло захопити й ліквідувати одну особу (на 1 січня 1951 p. діяв 1 апарат); УМДБ східних областей здійснено 75 установок радіосигналізаційних апаратів «Тривога», з яких було прийнято 6 радіосигналів про появу підпільників, реалізовано 1, що дало змогу захопити й ліквідувати 1 націоналіста (на 1 січня 1951 р. діяли 3 апарати) (ГДА СБУ. Ф. 13. Спр. 372. Т. 90. Арк. 71).

Попри успішні приклади застосування радіосигналізаційної апаратури, існували суттєві недоліки у використанні цих пристроїв. У 1951 р. в оперативних заходах Управління 2-Н МДБ західних областей України використовувалося 272 апарати «Тривога», які передали 25 радіосигналів, 3 яких реалізували 16, при цьому ліквідували 43 підпільники; відповідно, у Львівській - 67/3/2/5, Станіславській - 16/5/5/14, Дрогобицькій - 75/5/2/6, Тернопільській - 16/0/0/0, Рівненській - 82/9/5/12, Волинській - 7/2/1/4, Закарпатській - 3/0/0/0, Чернівецькій - 0/0/0/0, східних областях - 6/1/1/2 (ГДА СБУ. Ф. 2-Н. Оп. 39 (1960). Спр. 9. Арк. 188). Загалом 219 підпільникам удалося втекти (ГДА СБУ. Ф. 2-Н. Оп. 39 (1960). Спр. 9. Арк. 20). Із шести випадків застосування апаратів «Тривога» в одному випадку (Галицький РВ МДБ) було ліквідовано трьох підпільників, однак в інших ситуаціях це результатів не давало. При цьому йшлося не про технічні недоліки, а про відсутність належної реакції РВ МДБ щодо негайного відправлення оперативно-військових груп за сигналом агентури (ГДА СБУ. Ф. 2-Н. Оп. 99 (1954). Спр. 8. Т. 8. Арк. 25). Мали місце й інші недоліки в роботі. Так, начальник 4-го відділу управління 2-Н МДБ УРСР інж.-майор Александров відзначав, що в УМДБ Станіславської області станом на 1 січня 1951 p. із 40 наявних у резерві апаратів «Тривога» було встановлено лише шість, із них у грудні 1949 р. - три. Використання радіосигналізаційної техніки відбувалася 3 перемінним успіхом. Наприклад, в УМДБ Станіславської області в 1949 р. було реалізовано 10 радіосигналів про появу підпільників, а в 1950 р. - лише один (Іщук, Ніколаєва, 2008: 156-157, 161).

Роботу зі встановлення радіосигналізаційних засобів продовжували й у наступні роки. Так, група радіозв'язку на чолі з начальником групи відділу 2-Н УМДБ Дрогобицької області, старшим технік-лейтенантом державної безпеки Бурим виділила 38 радіоапаратів «ТривогаБіс» для встановлення 31 січня до 20 листопада 1952 р. (ГДА СБУ. Ф. 2-Н. Оп. 99 (1954). Спр. 2. Т. 6. 
Арк. 169-170). Використання «Тривоги» в агентурно-оперативній роботі органів МДБ у західних областях України допомогло розв'язати одне 3 основних завдань - налагодити швидкий і конспіративний зв'язок з агентурою. Уміле застосування апаратів «Тривога» для сигналізації по радіо про появу підпільників надавало суттєву допомогу оперативно-військовим силам у справі їх розшуку й ліквідації (ГДА СБУ. Ф. 13. Спр. 372. Т. 90. Арк. 1).

Водночас використання апаратів «Тривога» мало певні недоліки: 1) з наявних в УМДБ апаратів функціонувало не більше 25-30\%, решта лежали на складах; 2) апарати встановлювалися лише в тих районах, де місцеві начальники райвідділів МДБ усвідомили реальні переваги радіотехніки в оперативній роботі, навіть більше, самі вимагали в обласного керівництва цю техніку; 3) керівники відділів 2-Н в обласних управліннях МДБ не змогли добитися застосування радіотехніки в районах, де найбільше було поширене підпілля; 4) через недостатньо добре поставлену загальну й агентурну роботу значна частина апаратів установлювалася в неперевірених осіб, у яких по кілька місяців пристрої простоювали безрезультатно; 5) частина агентів (під тиском обставин змушені були погодитися співпрацювати 3 МДБ) вели подвійну гру; зустрічалися й так звані двійники (за визначенням оперативників МДБ), які співпрацювали 3 двома сторонами. На думку емдебістів, про це свідчив той факт, що впродовж шести місяців 1950 р. у Дрогобицькій області приблизно 70 апаратів «стояли безрезультатно»; 6) окремі начальники райвідділів МДБ формально підходили до виконання вказівок і не надавали належного технічного забезпечення (ГДА СБУ. Ф. 13. Спр. 372. Т. 90. Арк. 11; Іщук, Ніколаєва, 2008: 158-159).

Проблеми з використанням технічних апаратів зумовлювалися також віддаленістю окремих населених пунктів від районних і міських центрів. Відтак час між отриманням сигналу і безпосередньо прибуттям на місце розтягувався на кілька годин, що давало змогу підпільникам відійти на безпечну відстань (ГДА СБУ. Ф. 2-Н. Оп. 99 (1954). Спр. 8. Т. 8. Арк. 24). За період 1949-1950 pp. офіційно зареєстровано 80 випадків запізнень із виїздами чекістсько-військових груп на прийняті сигнали до місць появи повстанців, унаслідок чого змогли втекти 193 підпільники (Іщук, Ніколаєва, 2008: 158). Констатувалося, що в багатьох РВ МДБ оперативний склад недооцінював значення апаратів «Тривога» і ставився до них скептично. Наприклад, начальник Перегінського РВ МДБ майор Дмитро Огорєлішев заявив: «Заберіть цю техніку! Вона мені не потрібна, я бандитів поб’ю і без неї» (ГДА СБУ. Ф. 2-Н. Оп. 99 (1954). Спр. 8. Т. 8. Арк. 25).

Ситуація вимагала від органів МДБ пошуку цілого комплексу нових, більш ефективних і конспіративних способів зв'язку з найбільш цінною агентурою, яка вела розробку керівних ланок націоналістичного підпілля та його збройних груп, що мало допомогти уникнути провалів, загибелі чи розконспірації цієї агентури. Розв'язуючи це завдання, управління 2-Н МДБ УРСР у травні 1948 р. розробило схему сигналізаційного радіопристрою автоматичної дії. Йому присвоїли індекс «Метео» (ГДА СБУ. Ф. 2-Н. Оп. 34 (1960). Спр. 2. Арк. 88), а призначення полягало в передачі агентом по радіо встановленого сигналу про місцезнаходження підпільників чи виклику оперативного працівника на зустріч для передачі важливої оперативної інформації.

Прилад «Метео» мав мінімальні габарити, що давало змогу встановлювати й таємно маскувати його у квартирі, надвірних будівлях, криївках, навіть закопати в землю, на дереві та інших місцях, зручних для агента. Його включення для автоматичної передачі чи умовних сигналів проводилося на відстані до сотні й більше метрів за допомогою простого замикання агентом кінців двох замаскованих дистанційних провідників. Радіус проходження сигналів міг бути збільшений або зменшений залежно від того, на якій відстані від приймального посту перебував агент 3 пристроєм. Установлення «Метео» проходило так: від нього (у штукатурці, під плінтусом, підлогою) виводилися два провідники дистанційного управління, які за різними варіантами підключалися до дверної ручки, внутрішнього запору дверей, двох цвяхів, убитих у стіну тощо. Увімкнення пристрою здійснювалося таємно й навіть у присутності повстанців: на цвяхи вішалося відро чи на них натискалося каблуком чобота із залізною підковою тощо. Для прийому радіосигналів було сконструйовано примітивний радіоприймач. Ним міг користуватися кожний оперативний працівник, який пройшов короткотермінову підготовку. Поряд із цим для передавальних цілей могли застосовуватися звичайні радіоприймачі. Установлення радіоприймача «Метео» займало 25-30 хв., а на його зняття необхідно було 8-10 хв.

Умовні сигнали, які видавав «Метео» агента, і схоплювані приймачем «ПК», що мав оперативний працівник, були простими: у вигляді точок чи тире азбуки Морзе. Перед установленням приладу «Метео» в агента оперативний працівник був зобов'язаний обумовити 3 ним, які дані та яким 
видом сигналу він буде передавати. Користування апаратом не вимагало спеціальної радіотехнічної підготовки, ним могли користуватися навіть неграмотні особи.

Перевірена дальність дії приладу «Метео» сягала 500 км. Проте доцільно було встановлювати пост прийому на такій відстані, щоб для прибуття за сигналом оперативника чи чекістсько-військової групи до агента чи іншого встановленого місця затрачалася мінімальна кількість часу (ГДА СБУ. Ф. 2-Н. Оп. 34 (1960). Спр. 2. Арк. 89). Перші зразки приладу «Метео» ще в червні 1948 р. були розіслані всім УМДБ західних областей і в кількох місцях установлені для роботи.

Управління 2-Н МДБ УРСР виготовило достатню кількість апаратів «Метео», які, починаючи 3 жовтня 1948 р., регулярно висилали на місця за заявками відділів 2-Н УМДБ (ГДА СБУ. Ф. 2-Н. Оп. 34 (1960). Спр. 2. Арк. 90; Ф. 13. Спр. 372. Т. 90. Арк. 129). За час від 1 до 7 листопада 1948 р. у західних областях ліквідовано 1037 осіб, із них вбито 61, арештовано 976. Втрати повстанців у Дрогобицькій області становили вбитими 23 особи, заарештованими 180; відповідно у Волинській - 6/121, Дрогобицькій 23/180, Львівській - 12/114, Рівненській - 4/73, Станіславській - 14/210; Чернівецькій - 0/17, Тернопільській - 2/258 (ГДА СБУ. Ф. 13. Спр. 372. Т. 90. Арк. 299).

Ще одним доволі поширеним спеціальним засобом у боротьбі проти ОУН і УПА стали службово-пошукові собаки. Наприклад, на території західних областей чекістсько-військовими групами органів МДБ упродовж 1949 р. використовувалися 444 службово-пошукові собаки, у тому числі в Дрогобицькій області - 63, Львівській 91, Тернопільській - 69, Рівненській - 68, Станіславській -119 , Волинській -34 . За час із 1 січня до 1 травня 1949 р. у такий спосіб ліквідували 52 підпільники, 3 них захоплено - 7, убито - 22, заарештовано - 23 (ГДА СБУ. Ф. 13. Спр. 372. Т. 90. Арк. 60). Попри доволі ефективний засіб ведення антиповстанської боротьби, самих собак суттєво бракувало. Так, генерал-майор Фадєєв склав спеціальну довідку генералу Дроздову. У ній писав, що у військах МДБ Українського округу належало за штатом 507 розшукових собак, але станом на 1 березня 1949 р. було тільки 410. Тобто на 97 собак менше за штатну необхідність. Згідно 3 розпорядженням ГУВВ МДБ СРСР, у середині квітня 1949 р. на укомплектування школи службового собаковедення в м. Броди Львівської області мало бути направлено 70 собак. При цьому в документі писалося, що таким чином загаль- ний некомплект по військах округу становив 167 собак. Для покриття цього некомплекту на закупівлю собак МДБ СРСР виділило 400 тис. рублів, але фінансовим відділом МДБ СРСР запропоновано проводити закупівлю тільки в організаціях Добровільного об'єднання сприяння армії (далі - ДОСАРМ), натомість у приватних осіб закупівля собак, навіть зареєстрованих у ДОСАРМ, заборонялася. Через відсутність собак в організаціях ДОСАРМ використовувати виділені засоби не було можливим. Водночас Фадєєв наводив штатну розстановку й наявність розшукових собак по військових частинах: по 62 стрілецькій дивізії внутрішніх військ МДБ $(4,10,88,91,332$ стрілецькі полки) по штату мало бути 195 собак, реально було 144, відтак 51 некомплект; 65 стрілецька дивізія ( 3 омсб, 86, 450 сп) по штату мало бути 78, реально63,15 - некомплект, 81 стрілецька дивізія $(227,445$, 446 сп) по штату мало бути 117, реально - 105, 12 некомплект; 82 стрілецька дивізія $(215,331,333$ сп) по штату мало бути 117, реально - 98, 19 некомплект. Загалом по Українському округу мало бути 507 собак, реально - 410, 97 некомплект (Архів внутрішніх військ. Т. 232. Арк. 181-184).

У документах збереглося немало відомостей про практичне використання службово-розшукових собак. Так, у Дрогобицькій області 1 березня 1949 р. військова група 2-го батальйону 91-го полку ВВ МДБ з інструктором службових собак Мельниковим і пошуковим собакою «Дінкою» проводила операцію 3 розшуку підпільників у лісовому масиві Старосамбірського р-ну. Незабаром собака знайшов криївку, у якій перебували 11 підпільників. На пропозицію здатися вони відкрили вогонь, але в бою 10 із них загинули, а один був захоплений. Так був повністю ліквідований Самбірський надрайонний провід (ГДА СБУ. Ф. 13. Спр. 372. Т. 90. Арк. 61). При використанні службово-розшукових собак важливе місце відводилося інструкторам. Саме вони перебували в особливому, привілейованому, статусі, що, наприклад, виявлялося в забороні ставити їх у добові чергування по підрозділу (Вєдєнєєв, Биструхін, 2007: 326).

Оскільки використання службово-розшукових собак становило серйозну небезпеку, підпільники розробили рекомендації щодо поведінки в таких випадках. Так, щоб збити собаку зі сліду, націоналісти посипали сліди перцем, змащували підошви взуття бензином, ацетоном, іншими речовинами, які мали різкий запах. При безпосередньому зіткненні з чекістсько-військовими групами, які використовували розшукових собак, повстанці намагалися одразу їх ліквідувати (Іщук, Ніколаєва, 2008: 135, 137). 
Відповідно до рекомендацій ЦК КП(б)У щодо проведення оперативних заходів з ліквідації українського підпілля, органи НКВС широко практикували використання так званих «npuманок» (цінні речі, продовольчі товари, агенти, рідше радянські чиновники) (ГДА СБУ. Ф. 13. Спр. 372. Т. 90. Арк. 125-126; Ф. 71. Оп. 6. Спр. 44. Арк. 1-3). Проблема використання приманок постійно обговорювалася на різного рівня нарадах, навіть більше, у рішенні ЦК КП(б)У від 27 листопада 1945 р. був відповідний пункт, у якому передбачалося використання приманок. На нараді у Львові 4 січня 1946 р. М. Хрущов виокремлював керівництво Станіславської області, яке, на його думку, було нездатне виконувати рішення ЦК КП(б)У щодо належної організації приманок. При цьому наголошувалося, що зі 162 проведених приманок безрезультатними виявилися 144 (ДАІФО. Ф. 1-П. Оп. 1. Спр. 393. Арк. 4). Мали місце приписки й фальсифікації у звітних документах. Так, начальник Жовтневого РВ НКВС Станіславської області звітував про організацію та проведення 11 приманок, начальник райвідділу НКВС доніс в обласне управління НКВС про 15, а при виїзді та їх перевірці виявили лише вісім. Тобто, як бачимо, чекісти полюбляли здійснювати 50\% приписок. Серйозність цього заходу засвідчує й приклад начальника райвідділу Болехівського НКВС Станіславської області Травкіна, якого за неорганізацію приманок, ВБ і масових викликів населення для бесід заарештували на 15 діб і зняли з роботи (ДАІФО. Ф. 1-П. Оп. 1. Спр. 393. Арк. 5, 8). Упродовж 5-23 лютого 1946 p. на території Станіславської області організували й провели 733 чекістсько-військові операції та 442 засідки, у тому числі 33 з приманками, у ході яких повністю було ліквідовано 10 збройних груп (Літопис УПА. Нова серія. Т. 5, 2002: 80). До речі, матеріали спецслужб наводили десятки прикладів успішно організованих і проведених засідок із використанням приманок (ГДА СБУ. Ф. 71. Оп. 6. Спр. 44. Арк. 34-35).

Паралельно 3 наведеними вище спецзасобами для захоплення підпільників живими застосовували снодійні й отруйні препарати. Перші такі спроби зафіксовані ще під час «великої блокади». Одним із них був засіб «Нептун» (майже не мав запаху та смаку, розроблений в одній із відомчих лабораторій МДБ СРСР), який надійні агенти підсипали в їжу. Про хімічний склад цієї рідини достеменно невідомо (можливо, це скополамін: викликає галюцинації й сухість у роті, використовувався під час допитів). Саме через це ті, кому підсипали хімічні засоби, не підозрювали про їх наявність. Після споживання отрути, через п'ятьшість хвилин, мліли кінцівки, людина втрачала контроль над собою, здатність пересуватися або ж засинала на шість-вісім годин. Після пробудження свідомість близько години залишалася затьмареною, мучили сильна спрага й головний біль. Це вважалося зручним моментом для проведення «активного допиту» (Політичний терор і тероризм в Україні..., 2002: 763; Іщук, Ніколаєва, 2008: 146; ГДА СБУ. Ф. 13. Спр. 372. Т. 77. Арк. 175-177). Використання снодійних препаратів чекісти ретельно маскували. Різноманітні види снодійних засобів віднайти не вдалося, про використання такого типу матеріалів довідуємося 3 дотичних джерел. Так, в акті від 2 жовтня 1952 р. зазначалося: оперуповноважений капітан державної безпеки Скляр і старший оперуповноважений Управління 2-Н МДБ УРСР майор держбезпеки Горбивненко склали акт, що перший здав, а другий прийняв 20 різноманітних варіантів засобів. Крім цього, були також таблетки проти сп'яніння й таблетка отрути (ГДА СБУ. Ф. 2-Н. Оп. 99 (1954). Спр. 8. Т. 5. Арк. 358).

Практичне використання снодійних засобів відбувалося так. Для захоплення підпільників «Тараса» i «Чорноти» агент «Береза» використав спецзасіб «Нептун». «Береза» був споряджений «Нептуном» № 12 (для сала), № 46 (для вина) і пістолетом ТТ для ліквідації підпільників на випадок неможливості застосування спеціальних засобів. Для зв'язку з «Березою» та надання йому допомоги в захопленні підпільників було створено й 17 травня 1954 р. таємно розташовано на лісовій ділянці «Довга Поляна» оперативно-чекістську групу під керівництвом заступника Уповноваженого апарату КДБ Перегінського району капітана Захарова. Уранці 27 травня 1954 р. до оперативної групи з'явився агент «Береза», який повідомив таке: 26 травня він зустрічався 3 «Тарасом» i «Чорнотою», пригощав їх хлібом, молоком і планував зустрітися 3 ними 27 травня, де мав намір застосувати «Нептун». 27 травня 1954 р. о 18.00. «Береза» у стані сильного сп'яніння повторно з'явився до оперативної групи й доповів: підпільники «Тарас» i «Чорнота» випили вино, заправлене «Нептуном» № 46, і сплять на відстані двох кілометрів від оперативної групи в лісі на схилі однієї з гір. «Тарас» був захоплений та обеззброєний на вказаному агентом місці. Підпільник «Чорнота» (який прийняв меншу дозу), побачивши солдатів, намагався здійснити збройний супротив. Його було ліквідовано. Убитим виявився член кур'єрської групи Карпатського краю Зиновій Халусяк-«Чорнота», а захопленим - комен- 
дант охорони керівників Карпатського краю Дмитро Мельник-«Тарас» (ГДА СБУ. Ф. 2-Н. Оп. 19 (1959). Спр. 16. Арк. 136-137). Отже, дія спецпрепарату не завжди допомагала захопити підпільників живими (ГДА СБУ. Ф. 2-Н. Оп. 99 (1954). Спр. 2. Т. 1. Арк. 49).

Радянські силові органи поширювали серед агентів отруту (iі додавали до води та їжі повстанців) для знищення учасників УПА та членів ОУН. За твердженням повстанської преси, на чорному ринку масово під виглядом вакцини продавалися препарати зі збудниками різних інфекцій (Літопис УПА. Т. 9, 1982: 163).

Чекісти, особливо на початкових етапах, досить часто проводили комбіновані операції для знищення керівників. Зокрема, їм вдалося підсадити інформатора «Кобзаря» до санітарки Станиславівського надрайонного проводу ОУН Марії Духович«Ольги». Від неї він довідався й передав чекістам, що вона боїться арешту, а також те, що в підпіллі віддано наказ усім озброїтися ціанистим калієм на випадок захоплення (щоб покінчити життя самогубством). Інформатор налагодив із «Ольгою» довірливі зв'язки, 12 жовтня 1945 р. вона просила «Кобзаря» придбати для Я. Мельника-«Роберта» медикаменти, оскільки він захворів на запалення легень. Інформатор за власною ініціативою ввів значну дозу стрихніну в порошок кальцеуму й тонофосфону, щоб отруїти «Роберта». Він розраховував на те, що отруєння за допомогою цих препаратів відбудеться не одразу, а приблизно через чотири-п'ять днів. За повідомленням зв'язкової «Ольги», яка 4 листопада 1945 р. відвідала інформатора «Кобзаря», чекістам стало відомо, що медикаменти 3 уведеною дозою стрихніну «Ольгою» отримані й «Роберт» їх прийняв. За даними тієї ж зв'язкової, після прийняття ліків стан здоров'я «Роберта» різко погіршився, він нібито перебував у тяжкому стані, майже не розмовляв (скоріш за все це була комбінація СБ ОУН, оскільки відомостей про поранення Я. Мельника немає) (ГДА СБУ. Ф. 2-Н. Оп. 93 (1954). Спр. 2. Арк. 9, 11; Оп. 75 (1953). Спр. 8. Арк. 43).

При цьому спецслужби робили акцент на особистих зустрічах і через зв'язки використовували іiі наосліп для розробки підпілля, сподіваючись на те, що «Ольга» повністю довірилася «Кобзареві» й почне направляти в лікарню на лікування керівних працівників ОУН, яких чекісти при відповідних комбінаціях зможуть арештовувати. Крім цього, через «Ольгу» мали намір вийти на розробку «Роберта» й інших важливих оунівців для захоплення чи ліквідації (ГДА СБУ. Ф. 2-Н. Оп. 93 (1954). Спр. 2. Арк. 12).
14-15 січня 1946 р. М. Духович-«Ольга» через зв'язкову надіслала листа «Кобзареві», у якому повідомляла, що «Роберт» був тяжко поранений $\mathrm{i}$ перебував на їі особистому забезпеченні. У листі вона просила поради, що потрібно робити при пораненні в ділянку легень, і допомоги медикаментами. «Кобзар» за завданням спецслужб запропонував свої послуги, погоджуючись або виїхати на місце чи, якщо «Роберт» забажає, доправити його під виглядом постраждалого від підпільників мешканця села до лікарні. «Ользі» було відомо, що «Кобзар» мав такі можливості. За завданням чекістів він передав «Ользі» необхідні для «Роберта» медикаменти (ГДА СБУ. Ф. 2-Н. Оп. 93 (1954). Спр. 2. Арк. 23). Керівництво ОУН та УПА добре знало, що чекісти розробили спеціальні отруйні засоби, які вручали своїм інформаторам та агентам із завданням отруювати й захоплювати націоналістів живими. У зв'язку з цим Служба безпеки ОУН розробила 26 березня 1949 р. спеціальну інструкцію «Про снодійні засоби», у якій окреслила заходи щодо запобігання отруєнням. Ї̈̈ доводили до відома всіх підпільників для впровадження в життя. Автором інструкції був підпільник «Т-48» (імовірно, це окружний референт СБ Коломийщини Роман Тучак-«Клим») (Проданик, 2011: 35-36).

Водночас у підпіллі була розроблена спеціальна «Пересторога» (26 березня 1949 р.) про використання МДБ отруйних речовин. У ній зазначалося, що агенти отруюють харчові продукти (товщ, мед, цукор, борошно, консерви, цигарки тощо), які населення жертвує на потреби підпілля. Щоб запобігти можливому отруєнню, рекомендувалося: при підготовці харчових продуктів чи інших речей попереджати населення, що у випадку отруєння підпільників наданими харчами їх притягуватимуть до суворої відповідальності; усі харчові продукти, які походять від підозрілих осіб, продавати на ринках емдебістам, партійцям та іншим працівникам радянської адміністрації, а за ті самі гроші купувати крам у перевірених людей. Аналогічно рекомендували заготовлювати ліки й перев'язочний матеріал; папір, кальку, матриці, фарби, що переходили через підозрілі руки, перепродувати, а за ті гроші купувати інші; намагатися взагалі не їсти в хатах, а при споживанні харчів просити когось із господарів першими скуштувати; заборонялося одночасно їсти всім в одному будинку; збираючи харчі, не дозволялося складати їх в один мішок, а з кожної хати - окремо; перед початком уживання харчі варто старанно оглянути, понюхати, скуштувати; у приміщенні, де перебували підпільники, бажано 
було мати кота, якому давати на пробу харчі (ГДА СБУ. Ф. 13. Спр. 376. Т. 29. Арк. 318). У цій інструкції підпільники писали, що силовики через агентуру продавали підпільникам радіоапарати, у яких були вмонтовані передавачі. Саме завдяки ним вони легко віднаходили приміщення, де вмикалися такі апарати. Ще один конкретний випадок наводять у цьому документі: продаж підпільникам батареї до радіоприймачів із закладеною в них вибухівкою. Наводили випадок загибелі 10 липня 1948 р. у лісі біля с. Луг Яремчанського району Станіславської області внаслідок вибуху провідника Надвірнянського надрайонного проводу ОУН Михайла Іваніщака-«Діброви». Зокрема, відбулася ця спецоперація за таких обставин: 9 липня 1948 р. через агента «Червона» силовики передали учасникам боївки СБ Яремчанського районного проводу ОУН радіоприймач із батареєю, у яку заклали заміновану анодну батарею «БАС-80», розраховуючи при іiі підключенні до приймача на коротке замикання й миттєвий вибух (ГДА СБУ. Ф. 2-Н. Оп. 98 (1954). Спр. 13. Т. 1. Арк. 54). Указаний приймач учасники боївки СБ Яремчанського районного проводу ОУН «Тарас» i «Ромко» віднесли в криївку, розташовану в гірсько-лісистій місцевості, прилеглій до села Луг Яремчанського району Станіславської області. Об 11.0010 липня 1948 р. при підключенні батареї до радіоприймача відбувся вибух, у результаті якого в криївці серед інших загинув провідник Надвірнянського надрайонного проводу ОУН - Михайло Іщак-«Богдан» (ГДА СБУ. Ф. 2-Н. Оп. 98 (1954). Спр. 13. Т. 1. Арк. 54). Саме через це рекомендувалося ретельно перевіряти шляхи одержання радіоапаратів і батарей живлення до них, навіть після цього перевіряти їх, краще було користуватися старими радіоапаратами. Якщо траплялися такі випадки, ретельно їх описувати та подавати детальні протоколи з підписами свідків (ГДА СБУ. Ф. 13. Спр. 376. Т. 29. Арк. 319).

На початку 1950-х рр. фахівці радянських спецслужб розробили спеціальний снодійний газ миттєвої дії «Тайфун», який містився в ручних балонах і вводився у вентиляційні отвори криївок через гнучкий шланг. Недоліком його було те, що під час застосування відбувався гучний хлопок, і підпільники могли встигнути застрелитися. До речі, він не завжди спрацьовував, як у випадку спроби захопити М. Твердохліба (травень 1954 р.) (Вєдєнєєв, Биструхін, 2007: 299).

Іншим спецзасобом стало поширення венеричних та інших недуг. У всіх західних областях України військові, прикордонні частини перетворилися на розсадники вензахворювань, яких до цього часу в регіоні майже не було. За твердженням підпільників, у Нижньоустрицькому районі внаслідок квартирування частин НКВС у кожному селі з'явилися 10-20 венерично хворих жінок. Наприклад, у селах Турківського р-ну наприкінці 1948 р. за неповними даними венерично хворих осіб було: Вовче - 18, Боберка - 10 , Дністрик-Дубовий - 5, Ісаїв - 250, Явора - 12, Розлуч - 37, Присліп - 2, Жукотин - 3 (ГДА СБУ. Ф. 13. Спр. 376. Т. 73. Арк. 139). Із в’язниць були звільнені інфекційно хворі особи для поширення захворювань серед повстанців (Літопис УПА. Т. 9, 1982: 163).

Практикували силовики також і підробку ділової кореспонденції підпільників. За інформацією дослідника історії спецслужб Д. Вєдєнєєва, важливе місце в антиповстанських оперативно-розшукових заходах радянських спецслужб відводилося експертно-криміналістичним дослідженням. Відповідно до рішення ЦК ВКП(б) від 4 травня 1946 р., у структурі МДБ СРСР запроваджено відділи «В» (перлюстрація документів) і «Д» (експертиза й виготовлення документів). До початку 1950-х pp. уже існувало 46 кабінетів експертиз документів (Вєдєнєєв, Биструхін, 2007: 300). Головним у роботі таких спецлабораторій була підробка підпільної кореспонденції. Колишній працівник спецслужб Г. Санніков згадував про один із таких випадків у Києві: «Їх було всього двоє (спеціалістів) [...] І вся хитрість - столик 3 матовим склом, підсвічений світлою лампою знизу, тонка, щільна, як тютюновий папір калька, по якій виводилася точна копія почерку об'єкта». Для ефективної підробки кореспонденції спеціалісти вивчали особливості західноукраїнських говорів, методи шифрування. Такий напрям роботи давав змогу компрометувати окремих підпільників, що, безумовно, призводило до їх знищення (Проданик, 2011: 25). Наприклад, досвідчені оперативники УМДБ Станіславської області почерком крайового референта СБ Карпатського краю ОУН Миколи Твердохліба-«Грома» виготовили записку до провідника Коломийського окружного проводу Івана Кулика-«Сірого» (на той час уже загиблого - авт.) та залишили на «мертвому» пункті зв'язку окружного есбіста «Клима». У ній зазначалося, що сам «Грім» прийти на зустріч не зможе, тому висилає «представника» крайового проводу. Також до Косівського району спрямована агентурно-бойова група відділу 2-Н УМДБ Станіславської області. Агенти-бойовики виконували роль зв'язківців Карпатського крайового проводу ОУН та охоронців «провідників» (Проданик, 2012: 60). 
Репресивно-каральні органи впродовж 1945-1954 pр. намагалися скомпрометувати більшість керівного складу ОУН та УПА. Логічно, що спецслужби цікавилися передусім керівниками підпілля не тільки, щоб обезголовити визвольний рух, а й посіяти недовіру низових членів до керівництва. Так, чекісти встановили, що Костянтин Петер-«Сокіл» дуже любить свою сім’ю і боїться, щоб іiі не вислали до Сибіру, виявивши водночас, що його дружина й дочка ховалися в себе вдома в криївці. Не маючи змоги фізично його ліквідувати, вирішили провести комбінацію з компрометації «Сокола». 10 жовтня 1945 p. УНКВС Станіславської області на ім'я К. Петера направило листа: «Шановний Петере! Дякую Вам за інформацію, але повинен Вас попередити, що стара форма зв'язку мені здається зараз ненадійною, тому я вважаю необхідним організувати зв'язок через Ліну. [...] Попереджую Вас про обережність. Повідомте, що вам необхідно. За сім'ю не хвилюйтеся, iї ніхто не зачепить. Бажаю здоров'я і успіхів. Надіюсь скоро зустрінемося. Олександров» (ГДА СБУ. Ф. 2-Н. Оп. 75 (1953). Спр. 6. Арк. 110). Листа К. Петеру було направлено через агента-двійника 3 таким розрахунком, щоб він потрапив до рук СБ і водночас його сім'ю відвідали працівники НКВС. Як й очікувалося, лист потрапив до рук СБ, після чого «Сокола» від займаної посади відсторонили, хоч і не розстріляли (ГДА СБУ. Ф. 2-Н. Оп. 75 (1953). Спр. 6. Арк. 109-110).

Окремі компрометаційно-провокаційні операції тривали навіть більше року. Попри незначну чисельність підпілля на Чернівеччині, місцеві спецслужби особливо активно використовували цей метод боротьби. Так, упродовж цілого 1945 р. відділ ББ УНКВС Чернівецької області реалізовував дві агентурні комбінації, використовуючи захопленого обласного військового референта Мирослава Гайдука-«Федора» для компрометації провідника Миколи Кричуна-«Черемшини». Основна мета полягала в тому, щоб керівництво Буковинської округи ОУН, запідозривши його у співпраці 3 репресивно-каральними органами, дало завдання СБ ОУН допитати його та ліквідувати (Проданик, 2012: 19).

До найбільш характерних прикладів застосування провокацій $з$ метою компрометації керівного складу належить ще й така. Навесні 1947 р., здійснюючи розробку агентурної справи «Верховинці», за показами затриманого працівника референтури СБ Тлумацького надрайонного проводу ОУН Миколи Щербини-«Шугая», чекістам стало відомо, що керівництво Станіславівського окруж- ного і Тлумацького надрайонного проводів ОУН висловлює недовіру референту СБ крайового проводу ОУН В. Лівому-«Митарю». Крім цього, серед захоплених документів при ліквідації референта СБ Проводу ОУН М. Арсенича-«Михайла» була вилучена копія його листа до провідника крайового ОУН Я. Мельника-«Роберта», у якому він підозрював «Митаря» у зв'язках з органами МДБ. Підозра до «Митаря» в «Михайла» виникла ще 1944 р. під час розгрому в Богородчанському районі сотні Івана Гонти-«Гамалії», яка тоді прикривала обласний провід. У цьому бою «Михайло» втратив чотирьох своїх охоронців, а «Митар» утік і залишив його без прикриття. Репресивно-каральні органи склали окремий детальний план заходів компрометації «Митаря» перед підпіллям, які, однак, не увінчалися успіхом (ГДА СБУ. Ф. 2-Н. Оп. 93 (1954). Спр. 1. Арк. 41-42; Оп. 57 (1953). Спр. 1. Т. 2. Арк. 129-130).

Чекісти писали, що від 1 жовтня 1945 р. до 1 січня 1946 р. агентурою були скомпрометовані чотири підпільники 3 боївки «Шпака», три - 3 боївки «Левка», військовий референт Калуського окружного проводу ОУН Констянтин Петер«Сокіл», військовий референт Коломийського окружного проводу ОУН Микола Яворський«Козак», сотенний «Комар» і низка інших керівників і рядових членів ОУН і УПА (ГДА СБУ. Ф. 2-Н. Оп. 55 (1953). Спр. 5. Т. 1. Арк. 351).

Ціла низка провокацій репресивно-каральних органів була успішною (ГДА СБУ. Ф. 13. Спр. 372. Т. 77. Арк. 144-145; Ф. 2-Н. Оп. 60 (1953). Спр. 16. Арк. 160-161). Емдебісти часто використовували компрометації та провокації не лише для знищення конкретних підпільників, а й для того, щоб відвести підозри й законспірувати власного особливо цінного агента (ГДА СБУ. Ф. 13. Спр. 372. Т. 64. Арк. 316-317; Т. 95. Арк. 88-89; Ф. 2-Н. Оп. 57 (1953). Спр. 1. Т. 5. Арк. 202-203).

Здійснити підрахунки використання компрометаційно-провокаційних заходів, а головне, їх результативності не маємо змоги через відсутність відповідних джерел. Однак наявні фрагментарні дані засвідчують масовість та ефективність використання компрометації окремих членів підпілля. У 1947 р. у Дрогобицькій області чекісти відверто пишалися своїми успіхами у справі компрометації учасників підпілля. Лише впродовж 1947 р. було проведено 16 таких комбінацій членів ОУН та УПА, унаслідок яких знищено 28 підпільників і повстанців (ГДА СБУ. Ф. 13. Спр. 372. Т. 95. Арк. 306; Ф. 71. Оп. 6. Спр. 181. Арк. 1зв.). У червні 1948 р. міськрайвідділами МДБ Дрогобицької області проведено п'ять комбінацій, у результаті 
яких самими ж підпільниками було вбито сімох активних учасників ОУН та УПА. У вересніжовтні проведено вісім комбінацій, загинули 12 активних націоналістів (ГДА СБУ. Ф. 13. Спр. 372. Т. 55. Арк. 178; Ф. 71. Оп. 6. Спр. 180. Арк. 184). Усього впродовж 1 січня - 1 грудня 1946 р. у західних областях України проведено 1208 операцій, із них - 268 вдалих; відповідно, у Волинській області - 93 комбінації, у тому числі чотири вдалі; Дрогобицькій - 314/101; Львівській - 68/31; Рівненській - 90/45; Станіславській - 536/55; Тернопільській - 78/30; Чернівецькій - 29/2 (ГДА СБУ. Ф. 2-Н. Оп. 70 (1953). Спр. 6. Т. 2. Арк. 23-24).

Підпільні умови й компетентність окремих есбістів не завжди забезпечували ретельність слідчих дій і детальний аналіз кожної ситуації, через що траплялися випадки знищення окремих підпільників і керівників після відповідно проведеної компрометації (ГДА СБУ. Ф. 2-Н. Оп. 59 (1953). Спр. 6. Т. 1. Арк. 16-17, 84-85). До речі, варто сказати, що досить значний відсоток компрометаційних заходів не увінчувався успіхом особливо на Буковині (ГДА СБУ. Ф. 2-Н. Оп. 60 (1953). Спр. 14. Арк. 87).

Часто чекісти використовували слабкості самих підпільників, їхню схильність до незначних проступків (відвідини родини, населених пунктів поодинці тощо). Усі компрометації на керівний склад погоджувалися 3 керівництвом МДБ УРСР. Так, заступник міністра державної безпеки УРСР генерал-майор В. Дроздов 14 червня 1950 р. писав начальникові УМДБ Дрогобицької області полковникові Миколі Морозу, що вони переглянули розроблені два плани й уважають, що в першому і другому є недоліки, при цьому доцільно використати частину першого і другого (ГДА СБУ. Ф. 2-Н. Оп. 60 (1953). Спр. 16. Арк. 356-357).

Оперуповноважений Бориславського міського відділу МДБ молодший лейтенант Леонід Жданов 21 вересня 1948 р., перебуваючи в смт Східниця (із завданням ліквідації «Коваленка») отримав від таємного інформатора «Михайлова» дані, що провідник Дрогобицького районного проводу ОУН «Коваленко» перебуває в смт Східниця і що він повинен відвідати будинок мешканки цього села Баран. Замість прийняти ефективні заходи 3 розшуку й ліквідації «Коваленка», Жданов, зайшовши у квартиру мешканця смт Східниця Климовського, напився й намагався вступити в інтимний зв'язок із його дружиною Катериною Климовською, розголошуючи при цьому наявність в МВ МДБ компрометуючих матеріалів на їі чоловіка. За ці порушення молодшого лейтенанта за висновком Особливої інспекції ОК УМДБ
Дрогобицької області заарештовано на 10 діб без виконання службових обов'язків (ГДА СБУ. Ф. 71. Оп. 6. Спр. 624. Арк. 76; Оп. 10. Спр. 25. Арк. 140).

15 вересня 1948 р. начальник Дрогобицького РВ МДБ Дрогобицької області підполковник Журавльов склав план компрометації перед підпіллям районного провідника ОУН Свгена Войтовича-«Коваленка» (затвердив начальник УМДБ Дрогобицької області полковник Мороз). Силовики писали, що в документах, вилучених у референта СБ Карпатського крайового проводу ОУН В. Лівого-«Йордана» Є. Войтовича, характеризували: «Коваленко - провідник Дрогобицького району (9 осіб із сім’ї репресовані більшовиками) під час зими перебував у Дрогобичі, ходив у кінотеатр, їздив потягом, автомашинами, продукти доставляв у Губичі. Перебував у Губичах під час облави (де вбито 7 осіб і 1 захоплений живим), перебував в 10 м. від цього будинку». Саме тому силовики вирішили провести компрометацію районного провідника «Коваленка» перед оунівським підпіллям. Для цього прописали в нібито плані «роботи» 3 Є. Войтовичом: 1. Написати рапорт начальнику УМДБ Дрогобицької області в такому змісті, що Є. Войтович-«Коваленко» надає допомогу органам державної безпеки. Навіть деталізувалася ця допомога: а) на явці, яка відбулася в березні 1948 р. у м. Бориславі, Є. Войтович повідомив, що в ніч із 27 на 28 березня 1948 р. буде перебувати боївка «Макомацького», а він сам знаходитиметься в іншому будинку (у результаті цієї операції було вбито 5 осіб, а 2 заарештовано). 2. У м. Борислав на явці в липні 1948 р. «Коваленко» повідомив, що заступник референта СБ Роман Веприк-«Вільха» разом із двома особами повинні зустрітися зі станичним ОУН с. Зимівки, підпільником «Гордим» біля будинку Олексія Колоса. У ніч із 15 на 16 липня 1948 р., після отримання таких даних, була проведена військова операція 3 ліквідації підпільників, у результаті якої загинули Роман Веприк-«Вільха», кущовий провідник «Чумак» і був захоплений живим Микола Гладкий-«Крупняк». 3. У зимовий період 1947-1948 рр. «Коваленко» дуже часто перебував у м. Дрогобичі, з ним можна було легко зустрічатися. На одній із явок «Коваленко» повідомив про місцезнаходження провідника Дрогобицького міського проводу ОУН Лева Грущака«Левка», якого силовики вбили. У зимовий час 1948-1949 рр. зустрічі із «Коваленком» проводити було неможливо, оскільки останній перебував у криївці біля Східниці, з ним перебували троє підпільників, але тільки закінчиться зима і спаде сніг, зв’язок із «Коваленком» буде налагоджений. 
Просили начальника УМДБ за добру роботу преміювати «Коваленка» грошовою сумою в розмірі 2000 рублів та іменним годинником.

Зі слів захопленого «Буревія» силовики знали, що слідчий СБ Дрогобицького окружного проводу ОУН «Роман» переховувався в синевицькому лісі, періодично заходив у будинки на околиці с. Орів Дрогобицького району, а тому складений рапорт на ім'я начальника УМДБ непомітно планували залишити в будинку Анастасії Бабечко, яка мала зв’язок 3 «Оленем», останній перебував у криївці Богдана Зборика-«Романа», «Черника» (ГДА СБУ. Ф. 65. Спр. С-9278. Т. 1. Арк. 14-16).

Попри цю комбінацію чекістсько-військові операції не припинялися, складалися спеціальні плани 3 пошуку $\mathcal{C}$. Войтовича-«Коваленка» та осіб, які з ним перебували. Такий план був підготовлений і затверджений на період із 16 по 20 вересня 1948 р. (ГДА СБУ. Ф. 65. Спр. С-9278. Т. 1. Арк. 11-13). Крім того, була заведена справаформуляр на $Є$. Войтовича, у якій містяться звернення зі закликом про вихід із повинною (ГДА СБУ. Ф. 65. Спр. С-9278. Т. 1. Арк. 1-52).

Усе ж таки розроблена силовиками спецоперація увінчалася успіхом. Із вилучених у вбитого 15 травні 1949 р. провідника Дрогобицького окружного проводу ОУН І. Лавріва-«Нечая» документів було встановлено, що у вересні 1948 р. «Коваленко» був заарештований СБ, на слідстві під тортурами дав неправдиві покази, що $є$ агентом УМДБ Дрогобицької області під псевдонімом «Залізний», відтак був ліквідований самими підпільниками. Із цього приводу провідник Дрогобицького надррайонного проводу ОУН у штафеті від 21 вересня 1948 р. повідомляв «Нечаю»: «Коваленко є великим агентом-внутрішніком, завербований УМДБ у 1947 р., має за собою багато кривавих справ. За завданням МДБ створив в організації агентурну сітку, вів розробку робітників і студентів у містах Дрогобич і Борислав. Його протокол дуже багатий» (ГДА СБУ. Ф. 65. Спр. С-9278. Т. 1. Арк. 94).

Під компрометаційно-провокаційні заходи міг потрапити будь-хто, починаючи від симпатика, рядового підпільника й навіть провідника найвищого рівня. Особливий удар доводилося витримувати кущовим і районним керівникам (ГДА СБУ. Ф. 2-Н. Оп. 32 (1960). Спр. 7. Арк. 172зв.; Спр. 8. Арк. 15зв.; 55зв., 88, 124, 140зв.-141, 157зв., 178зв., 1863в.-187, 193зв.-195, 299; Спр. 10. Арк. 222-223, 264; Спр. 11. Арк. 67; Спр. 12. Арк. 146; Спр. 14. Арк. 231). Траплялися випадки компрометації цілих груп підпільників (ГДА СБУ. Ф. 13. Спр. 372. Т. 96. Арк. 26-27; Ф. 71. Оп. 6.
Спр. 53. Арк. 317-318). Окремі Управління МДБ настільки захопилися компрометаціями, що забували про інші форми роботи, тому навіть критикувалися вищим керівництвом.

Водночас поряд зі значною роботою $з$ компрометації перед оунівським підпіллям ця робота мала й недоліки. Так, були допущені випадки компрометації перед оунівським підпіллям осіб, які підтримували визвольний рух і членів ОУН, які проживали легально та яких радянські органи влади мали би розробляти, заарештовувати і притягувати до судової відповідальності. Компрометація окремих членів ОУН та осіб, які проживали легально, проводилася шляхом поширення серед місцевого населення чуток про співробітництво цих осіб із чекістськими органами, що призводило до розшифрування методів чекістської роботи (ГДА СБУ. Ф. 71. Оп. 6. Спр. 138. Арк. 91). Наголошувалося, що такий метод варто застосовувати тільки до осіб, які перебували в підпіллі, з метою знищення їх самими підпільниками (ГДА СБУ. Ф. 71. Оп. 6. Спр. 138. Арк. 92).

Поширеною провокацією було адресування звернень від начальників репресивно-карального апарату до підпільників певного району, у яких в ультимативній формі вимагалося виходити з повинною (ГДА СБУ. Ф. 13. Спр. 376. Т. 49. Арк. 289). Від імені начальника Дрогобицького управління НКВС О. Сабурова писали листи до референта СБ Дрогобицького надрайонного проводу ОУН Осипа Мицика-«Донського» й залишали в сільських хатах, щоб посіяти недовір'я серед підпільників і населення (Киричук, 2000: 194; Киричук, 2003: 242). Листування, проведення зборів і бесід серед місцевого населення, на яких зачитувалися списки підпільників, використовувалися поряд із різного роду чекістсько-військовими операціями, розкладанням відділів і для виводу із підпілля, схиляння до явки з повинною учасників відділів тощо.

Начальник УМДБ Чернівецької області навесні 1949 р. надіслав листа Петрові Іванишину-«Баші», уклавши в конверт листи колишнього курінного Назарія Данилюка-«Перебийноса» про есбістів, і рекомендував читати ці вірші націоналістам. Водночас він пропонував припинити збройну боротьбу, з'явитися з повинною до органів МДБ чи вийти на негласну зустріч зі співробітниками МДБ. Цей лист П. Іванишин передав тоді ж організаційному провідникові Буковинського окружного проводу ОУН Ю. Матвіїву-«Недобитому» в присутності референта СБ цього проводу Василя Паращука-«Макара». «Недобитий» передав ці документи «Сталю» для подальшого вирішення 
питання. Улітку 1949 р. П. Іванишин зустрівся 3 В. Савчаком-«Сталем». На питання про ставлення до листа начальника УМДБ він відповів, що ніколи не мав наміру з'являтися з повинною в органи МДБ, а тим більше виходити на таємну зустріч. «Сталь» схвалив це й заявив, що він зробить копію листа та направить референтові СБ Карпатського краю Миколі Твердохлібу-«Грому». Відтак П. Іванишин мав написати відповідь начальникові УМДБ у націоналістичному дусі, що члени ОУН не здаються й не мають наміру припиняти боротьбу проти органів радянської влади (ГДА СБУ. Ф. 2-Н. Оп. 108 (1954). Спр. 2. Т. 2. Арк. 10).

Ще одним засобом провокації підпілля було написання листів від колишніх захоплених підпільників до тих, хто продовжував боротьбу. Написані під диктовку оперативників МДБ, ці листи мали на меті не лише припинити опір, а й посіяти недовіру між націоналістами, сумніви в їхній свідомості, тим самим підвести до думки про недоцільність подальшого опору, а на завершальному етапі боротьби підпорядкувати останніх підпільників створеному чекістами легендованому проводу.
Висновки. Отже, у боротьбі з визвольним рухом репресивно-каральні органи не лише покладалися на військову силу, а й використовували різноманітні, в окремих випадках навіть «витончені» форми. Зокрема, масово застосовувалися спеціальні засоби, які поступово вдосконалювалися. На початкових етапах боротьби основним завданням, яке ставив репресивнокаральний апарат, було фізичне знищення членів ОУН та УПА. Згодом увага акцентувалася на захопленні підпільників живими 3 метою подальшого використання для ліквідації визвольного руху в Україні й для оперативних «ігор» із націоналістичними закордонними центрами. Водночас, не маючи можливості фізично знищити націоналіста (особливо керівника), спецслужби до свого арсеналу широко вводили компрометації. Для цього ретельно вивчали особистість підпільника, якого намагалися дискредитувати, його зв'язки, проступки, слабкості тощо. Попри значну частину ефективних компрометаційних заходів, траплялися провали, що, очевидно, зумовлювалося вмінням ретельно розібратися в обставинах Службою безпеки ОУН.

\section{СПИСОК ВИКОРИСТАНИХ ДЖЕРЕЛ}

1. Архів внутрішніх військ НКВС (далі - Архів ВВ НКВС). Т. 232. Арк. 181-184.

2. Білас I. Репресивно-каральна система в Україні 1917-1953. Суспільно-політичний та історичний аналіз : у 2 кн. Київ : Либідь; Військо України, 1994. Книга 2 : Документи та матеріали. 688 с.

3. Білас І. Репресивно-каральна система в Україні 1917-1953. Суспільно-політичний та історико-правовий аналіз : у 2 кн. Київ : Либідь ; Військо України, 1994. Книга 1. 432 с.

4. Вєдєнєєв Д., Биструхін Г. Двобій без компромісів. Протиборство спецпідрозділів ОУН та радянських сил спецоперацій. 1945-1980-ті роки. Київ : К.І.С., 2007. 568 с.

5. Галузевий державний архів Служби безпеки України (далі - ГДА СБУ). Ф. 2-Н. Оп. 55 (1953). Спр. 5. Т. 1.

6. ГДА СБУ. Ф. 2-Н. Оп. 57 (1953). Спр. 1. Т. 2.

7. ГДА СБУ. Ф. 2-Н. Оп. 57 (1953). Спр. 1. Т. 5.

8. ГДА СБУ. Ф. 2-Н. Оп. 59 (1953). Спр. 6. Т. 1.

9. ГДА СБУ. Ф. 2-Н. Оп. 60 (1953). Спр. 14.

10. ГДА СБУ. Ф. 2-Н. Оп. 60 (1953). Спр. 16.

11. ГДА СБУ. Ф. 2-Н. Оп. 70 (1953). Спр. 6. Т. 2.

12. ГДА СБУ. Ф. 2-Н. Оп. 75 (1953). Спр. 6.

13. ГДА СБУ. Ф. 2-Н. Оп. 75 (1953). Спр. 8.

14. ГДА СБУ. Ф. 2-Н. Оп. 93 (1954). Спр. 1.

15. ГДА СБУ. Ф. 2-Н. Оп. 93 (1954). Спр. 2.

16. ГДА СБУ. Ф. 2-Н. Оп. 98 (1954). Спр. 13. Т. 1.

17. ГДА СБУ. Ф. 2-Н. Оп. 99 (1954). Спр. 2. Т. 1.

18. ГДА СБУ. Ф. 2-Н. Оп. 99 (1954). Спр. 2. Т. 6.

19. ГДА СБУ. Ф. 2-Н. Оп. 99 (1954). Спр. 8. Т. 5.

20. ГДА СБУ. Ф. 2-Н. Оп. 99 (1954). Спр. 8. Т. 8.

21. ГДА СБУ. Ф. 2-Н. Оп. 108 (1954). Спр. 2. Т. 2.

22. ГДА СБУ. Ф. 2-Н. Оп. 19 (1959). Спр. 16.

23. ГДА СБУ. Ф. 2-Н. Оп. 32 (1960). Спр. 10.

24. ГДА СБУ. Ф. 2-Н. Оп. 32 (1960). Спр. 11.

25. ГДА СБУ. Ф. 2-Н. Оп. 32 (1960). Спр. 12.

26. ГДА СБУ. Ф. 2-Н. Оп. 32 (1960). Спр. 14.

27. ГДА СБУ. Ф. 2-Н. Оп. 32 (1960). Спр. 7.

28. ГДА СБУ. Ф. 2-Н. Оп. 32 (1960). Спр. 8.

29. ГДА СБУ. Ф. 2-Н. Оп. 34 (1960). Спр. 2. 
30. ГДА СБУ. Ф. 2-Н. Оп. 39 (1960). Спр. 9.

31. ГДА СБУ. Ф. 13. Спр. 372. Т. 55.

32. ГДА СБУ. Ф. 13. Спр. 372. Т. 56.

33. ГДА СБУ. Ф. 13. Спр. 372. Т. 64.

34. ГДА СБУ. Ф. 13. Спр. 372. Т. 77.

35. ГДА СБУ. Ф. 13. Спр. 372. Т. 90.

36. ГДА СБУ. Ф. 13. Спр. 372. Т. 95.

37. ГДА СБУ. Ф. 13. Спр. 372. Т. 96.

38. ГДА СБУ. Ф. 13. Спр. 376. Т. 29.

39. ГДА СБУ. Ф. 13. Спр. 376. Т. 49.

40. ГДА СБУ. Ф. 13. Спр. 376. Т. 73.

41. ГДА СБУ. Ф. 65. Спр. С-9278. Т. 1.

42. ГДА СБУ. Ф. 71. Оп. 6. Спр. 44.

43. ГДА СБУ. Ф. 71. Оп. 6. Спр. 53.

44. ГДА СБУ. Ф. 71. Оп. 6. Спр. 138.

45. ГДА СБУ. Ф. 71. Оп. 6. Спр. 180.

46. ГДА СБУ. Ф. 71. Оп. 6. Спр. 181.

47. ГДА СБУ. Ф. 71. Оп. 6. Спр. 624.

48. ГДА СБУ. Ф. 71. Оп. 10. Спр. 25.

49. Державний архів Івано-Франківської області (далі - ДАІФО). Ф. 1-П. Оп. 1. Спр. 393.

50. Ільницький В. Використання радянськими карально-репресивними органами спецзасобів у боротьбі проти визвольного руху у Карпатському краї ОУН (1945-1954). Проблеми гуманітарних наук: Наукові записки Дрогобицького державного педагогічного університету імені Івана Франка / ред.-кол. Н. Скотна (головний редактор), О. Петречко (редактор розділу) та ін. Дрогобич : Видавничий відділ ДдПУ імені Івана Франка, 2014. Випуск 34 : Історія. С. 76-86.

51. Ільницький В. Радянські карально-репресивні органи: особливості формування в Карпатському краї. Актуальні питання гуманітарних наук : міжвузівський збірник наукових праць молодих вчених Дрогобицького державного педагогічного університету імені Івана Франка / редактори-упорядники В. Ільницький, А. Душний, І. Зимомря. Дрогобич : Посвіт, 2015. Вип. 13. С. 21-45.

52. Ільницький В., Галів М. Створення та діяльність винищувальних батальйонів в Дрогобицькій області (1944-1948 рр.). Украӥнський визвольний рух / ред.-кол. В. В’ятрович, М. Гавришко, Я. Дашкевич, Р. Забілий (відп. редактор) та ін. Львів : Центр досліджень визвольного руху, Інститут українознавства ім. І. Крип'якевича НАН України, 2009. Вип. 13. С. 195-230.

53. Іщук О., Ніколаєва Н. Застосування радянськими спецслужбами допоміжних засобів у боротьбі з підпіллям ОУН та УПА. Украӥнський визвольний рух. Львів : Інститут українознавства ім. І. Крип'якевича НАН України, Центр досліджень визвольного руху, 2008. Збірник 12. С. 154-155.

54. Кентій А. Нарис боротьби ОУН-УПА в Україні (1946-1956 рр.). Київ : Інститут історії України НАН України, 1999. $111 \mathrm{c.}$

55. Кентій А. Українська повстанська армія в 1944-1945 рр. Київ : Інститут історії України НАН України, 1999. $220 \mathrm{c}$.

56. Киричук Ю. Нариси з історії українського національно-визвольного руху 40-50-х років ХХ століття. Львів : ЛДУ імені Івана Франка, 2000. 304 с.

57. Киричук Ю. Український національний рух 40-50-х років XX століття: ідеологія та практика. Львів : Добра справа, 2003. 464 с.

58. Літопис Української Повстанської Армії. Нова серія. Київ ; Торонто : Літопис УПА, 2002. Т. 5 : Боротьба проти УПА і націоналістичного підпілля: інформаційні документи ЦК КП(б)У, обкомів партії, НКВС-МВС, МДБКДБ (1943-1959) / упоряд. А. Кентій, В. Лозицький, І. Павленко]. Книга 2 : 1946-1947. 572 с.

59. Літопис Української Повстанської Армії. Т. 9 : Українська Головна Визвольна Рада. Документи, офіційні публікації, матеріяли / ред. кол. Є. Штендера, П. Потічний. Торонто : Літопис УПА, 1982. Книга 2 : 1946-1948. 520 с.

60. Політичний терор і тероризм в Україні. XIX-XX століття : історичні нариси / за ред. В. Смолія. Київ : Наукова думка, 2002. С. 763.

61. Проданик Д. Микола Кричун «Черемшина». Торонто ; Львів : Літопис УПА, 2012. Книга 19. 128 с. $128 \mathrm{c}$

62. Проданик Д. Шлях боротьби Василя Сенчака-«Ворона». Торонто ; Львів : Літопис УПА, 2011. Книга 15.

63. Русначенко А. Народ збурений: Національно-визвольний рух в Україні й національні рухи опору в Білорусії, Литві, Латвії, Естонії у 1940-50-х роках. Київ : Університетське видавництво «Пульсари», 2002. 519 с.

64. Сергійчук В. Десять буремних літ. Західноукраїнські землі у 1944-1953 рр. Нові документи і матеріали. Київ : Дніпро, 1998. 944 с.

65. Сергійчук В. Український здвиг : Прикарпаття. 1939-1955 рр. Київ : Українська видавнича спілка, 2005.840 с.

\section{REFERENCES}

1. Arkhiv vnutrishnikh viisk NKVS (dali-Arkhiv VV NKVS). [Archive of the Internal Troops of the People's Commissariat of Internal Affairs (hereinafter - the Archive of the People's Commissariat of Internal Affairs)] T. 232. Ark. 181-184. 
2. Bilas I. Represyvno-karalna systema v Ukraini 1917-1953. Suspilno-politychnyi ta istorychnyi analiz [Repressive and punitive system in Ukraine 1917-1953. Socio-political and historical analysis]. U dvokh knyhakh. Kyiv: Lybid; Viisko Ukrainy, 1994. Knyha druha: Dokumenty ta materialy. 688 s. [in Russian].

3. Bilas I. Represyvno-karalna systema v Ukraini 1917-1953. Suspilno-politychnyi ta istoryko-pravovyi analiz [Repressive and punitive system in Ukraine 1917-1953. Socio-political and historical-legal analysis]. U dvokh knyhakh. Kyiv: Lybid; Viisko Ukrainy, 1994. Kn. 1. 432 s. [in Ukrainian].

4. Viedienieiev D., Bystrukhin H. Dvobii bez kompromisiv. Protyborstvo spetspidrozdiliv OUN ta radianskykh syl spetsoperatsii. 1945-1980-ti roky [Duel without compromise. Confrontation between OUN special forces and Soviet special operations forces. 1945-1980]. Kyiv: K.I.S., 2007. 568 s. [in Ukrainian].

5. Haluzevyi derzhavnyi arkhiv Sluzhby bezpeky Ukrainy (dali-HDA SBU). F. 2-N. Op. 55 (1953). Spr. 5. T. 1.

6. HDA SBU. F. 2-N. Op. 57 (1953). Spr. 1. T. 2.

7. HDA SBU. F. 2-N. Op. 57 (1953). Spr. 1. T. 5.

8. HDA SBU. F. 2-N. Op. 59 (1953). Spr. 6. T. 1.

9. HDA SBU. F. 2-N. Op. 60 (1953). Spr. 14.

10. HDA SBU. F. 2-N. Op. 60 (1953). Spr. 16.

11. HDA SBU. F. 2-N. Op. 70 (1953). Spr. 6. T. 2.

12. HDA SBU. F. 2-N. Op. 75 (1953). Spr. 6.

13. HDA SBU. F. 2-N. Op. 75 (1953). Spr. 8.

14. HDA SBU. F. 2-N. Op. 93 (1954). Spr. 1.

15. HDA SBU. F. 2-N. Op. 93 (1954). Spr. 2.

16. HDA SBU. F. 2-N. Op. 98 (1954). Spr. 13. T. 1.

17. HDA SBU. F. 2-N. Op. 99 (1954). Spr. 2. T. 1.

18. HDA SBU. F. 2-N. Op. 99 (1954). Spr. 2. T. 6.

19. HDA SBU. F. 2-N. Op. 99 (1954). Spr. 8. T. 5.

20. HDA SBU. F. 2-N. Op. 99 (1954). Spr. 8. T. 8.

21. HDA SBU. F. 2-N. Op. 108 (1954). Spr. 2. T. 2.

22. HDA SBU. F. 2-N. Op. 19 (1959). Spr. 16.

23. HDA SBU. F. 2-N. Op. 32 (1960). Spr. 10.

24. HDA SBU. F. 2-N. Op. 32 (1960). Spr. 11.

25. HDA SBU. F. 2-N. Op. 32 (1960). Spr. 12.

26. HDA SBU. F. 2-N. Op. 32 (1960). Spr. 14.

27. HDA SBU. F. 2-N. Op. 32 (1960). Spr. 7.

28. HDA SBU. F. 2-N. Op. 32 (1960). Spr. 8.

29. HDA SBU. F. 2-N. Op. 34 (1960). Spr. 2.

30. HDA SBU. F. 2-N. Op. 39 (1960). Spr. 9.

31. HDA SBU. F. 13. Spr. 372. T. 55.

32. HDA SBU. F. 13. Spr. 372. T. 56.

33. HDA SBU. F. 13. Spr. 372. T. 64.

34. HDA SBU. F. 13. Spr. 372. T. 77.

35. HDA SBU. F. 13. Spr. 372. T. 90.

36. HDA SBU. F. 13. Spr. 372. T. 95.

37. HDA SBU. F. 13. Spr. 372. T. 96.

38. HDA SBU. F. 13. Spr. 376. T. 29.

39. HDA SBU. F. 13. Spr. 376. T. 49.

40. HDA SBU. F. 13. Spr. 376. T. 73.

41. HDA SBU. F. 65. Spr. S-9278. T. 1.

42. HDA SBU. F. 71. Op. 6. Spr. 44.

43. HDA SBU. F. 71. Op. 6. Spr. 53.

44. HDA SBU. F. 71. Op. 6. Spr. 138.

45. HDA SBU. F. 71. Op. 6. Spr. 180.

46. HDA SBU. F. 71. Op. 6. Spr. 181.

47. HDA SBU. F. 71. Op. 6. Spr. 624.

48. HDA SBU. F. 71. Op. 10. Spr. 25.

49. Derzhavnyi arkhiv Ivano-Frankivskoi oblasti (dali-DAIFO). F. 1-P. Op. 1. Spr. 393.

50. Ilnytskyi V. Vykorystannia radianskymy karalno-represyvnymy orhanamy spetszasobiv u borotbi proty vyzvolnoho rukhu u Karpatskomu krai OUN (1945-1954) [The use of special means by the Soviet punitive and repressive bodies in the struggle against the liberation movement in the Carpathian region of the OUN (1945-1954)]. Problemy humanitarnykh nauk: Naukovi zapysky Drohobytskoho derzhavnoho pedahohichnoho universytetu imeni Ivana Franka / [red.-kol. N. Skotna (holovnyi redaktor), O. Petrechko (redaktor rozdilu) ta in.]. Drohobych: Vydavnychyi viddil DDPU imeni Ivana Franka, 2014. Vypusk trydtsiat chetvertyi. Istoriia. S. 76-86 [in Ukrainian].

51. Ilnytskyi V. Radianski karalno-represyvni orhany: osoblyvosti formuvannia v Karpatskomu krai [Soviet punitive and repressive bodies: features of formation in the Carpathian region]. Aktualni pytannia humanitarnykh nauk: mizhvuzivskyi 
zbirnyk naukovykh prats molodykh vchenykh Drohobytskoho derzhavnoho pedahohichnoho universytetu imeni Ivana Franka. Drohobych: Posvit, 2015. Vyp. 13. S. 21-45 [in Ukrainian].

52. Ilnytskyi V., Haliv M. Stvorennia ta diialnist vynyshchuvalnykh batalioniv v Drohobytskii oblasti (1944-1948 rr.) [Creation and activity of fighter battalions in Drohobych region (1944-1948)]. Ukrainskyi vyzvolnyi rukh. Lviv: Tsentr doslidzhen vyzvolnoho rukhu, Instytut ukrainoznavstva im. I. Krypiakevycha NAN Ukrainy, 2009. Vyp. 13. S. 195-230 [in Ukrainian].

53. Ishchuk O., Nikolaieva N. Zastosuvannia radianskymy spetssluzhbamy dopomizhnykh zasobiv u borotbi z pidpilliam OUN ta UPA. Ukrainskyi vyzvolnyi rukh [The use of Soviet special services aids in the fight against the OUN and UPA underground. Ukrainian liberation movement]. Lviv: Instytut ukrainoznavstva im. I. Krypiakevycha NAN Ukrainy, Tsentr doslidzhen vyzvolnoho rukhu, 2008. Zbirnyk 12. S. 154-155 [in Ukrainian].

54. Kentii A. Narys borotby OUN-UPA v Ukraini (1946-1956 rr.) [Essay on the OUN-UPA struggle in Ukraine (1946-1956)]. Kyiv: Instytut istorii Ukrainy NAN Ukrainy, 1999. 111 s. [in Ukrainian].

55. Kentii A. Ukrainska povstanska armiia v 1944-1945 rr. [Ukrainian Insurgent Army in 1944-1945]. Kyiv: Instytut istorii Ukrainy NAN Ukrainy, 1999. 220 s. [in Ukrainian].

56. Kyrychuk Yu. Narysy z istorii ukrainskoho natsionalno-vyzvolnoho rukhu 40-50-kh rokiv XX stolittia [Essays on the history of the Ukrainian national liberation movement of the 40s-50s of the XX century]. Lviv: LDU imeni Ivana Franka, 2000. 304 s. [in Ukrainian].

57. Kyrychuk Yu. Ukrainskyi natsionalnyi rukh 40-50-kh rokiv XX stolittia: ideolohiia ta praktyka [Ukrainian national movement of the 40-50s of the XX century: ideology and practice]. Lviv: Dobra sprava, 2003. 464 s. [in Ukrainian].

58. Litopys Ukrainskoi Povstanskoi Armii. Nova seriia. T. 5: Borotba proty UPA i natsionalistychnoho pidpillia: informatsiini dokumenty TsK KP(b)U, obkomiv partii, NKVS-MVS, MDB-KDB (1943-1959) [The struggle against the UPA and the nationalist underground: information documents of the Central Committee of the $\mathrm{CP}(\mathrm{b}) \mathrm{U}$, regional committees of the party, NKVD-MVD, MDB-KGB (1943-1959)] / [uporiad. Anatolii Kentii, Volodymyr Lozytskyi, Iryna Pavlenko]. K.; Toronto: Litopys UPA, 2002. Kn. 2: 1946-1947. 572 s. [in Russian].

59. Litopys Ukrainskoi Povstanskoi Armii. T. 9: Ukrainska Holovna Vyzvolna Rada. Dokumenty, ofitsiini publikatsii, materiialy [Ukrainian Main Liberation Council. Documents, official publications, materials] [red.-kol. Yevhen Shtendera, Petro Potichnyi]. Knyha druha: 1946-1948. Toronto: Vydavnytstvo "Litopys UPA", 1982. 520 s. [in Ukrainian].

60. Politychnyi teror i teroryzm v Ukraini. XIX-XX stolittia. Istorychni narysy [Political terror and terrorism in Ukraine. XIX-XX centuries. Historical essays] / [za red. Valeriia Smoliia]. Kyiv: Naukova dumka, 2002. S. 763;

61. Prodanyk D. Mykola Krychun "Cheremshyna" [Mykola Krichun "Cheremshina”]. Toronto; Lviv: Litopys UPA, 2012. Kn. 19. 128 s. [in Ukrainian].

62. Prodanyk D. Shliakh borotby Vasylia Senchaka-"Vorona" [The way of struggle of Vasyl Senchak-"Crow"]. Toronto; Lviv: Vydavnytstvo "Litopys UPA", 2011. Kn. 15. 128 s. [in Ukrainian].

63. Rusnachenko A. Narod zburenyi: Natsionalno-vyzvolnyi rukh v Ukraini y natsionalni rukhy oporu v Bilorusii, Lytvi, Latvii, Estonii u 1940-50-kh rokakh [The people are upset: the National Liberation Movement in Ukraine and the national resistance movements in Belarus, Lithuania, Latvia, and Estonia in the 1940s and 1950s]. Kyiv: Universytetske vydavnytstvo "Pulsary", 2002. 519 s. [in Ukrainian].

64. Serhiichuk V. Desiat buremnykh lit. Zakhidnoukrainski zemli u 1944-1953 rr. [Ten turbulent years. Western Ukrainian lands in 1944-1953]. Novi dokumenty i materialy. Kyiv: Dnipro, 1998. 944 s. [in Russian].

65. Serhiichuk V. Ukrainskyi zdvyh: Prykarpattia. 1939-1955 rr. [Ukrainian shift: Prykarpattia. 1939-1955]. Kyiv: Ukrainska Vydavnycha Spilka, 2005. 840 s. [in Ukrainian]. 